\title{
An investigation on different factors influencing on target market selection in petrochemical industry
}

\author{
Saeedeh Koohi* and Ali Alikhani
}

Department of Management and Accounting, North Branch, Islamic Azad University, Tehran, Iran

\begin{tabular}{l}
\hline C H R O N I C L E \\
\hline Article history: \\
Received December 28, 2013 \\
Received in revised format April \\
152014 \\
Accepted April 182014 \\
Available online \\
April 23 2014 \\
\hline Keywords: \\
Petrochemical industry \\
Target market \\
Buyers' position
\end{tabular}
\begin{abstract}
A B S T R A C T
This paper presents an empirical investigation to determine important factors influencing on selection of petrochemical market. The survey has accomplished among 97 randomly selected experts in petrochemical industry in Iran. The survey designs a questionnaire and distributes it among some experts and using binomial test; it has confirmed that except one factor, cultural affairs, other issues including political, cultural, regulations, economic, infrastructure, market potential, buyers' potentials and buyer's positions influence on market development. The implementation of Freedman test has indicated that Buyers' positions are number one priority followed by buyers' potentials, rules and regulations.
\end{abstract}

\section{Introduction}

The choice of which country or countries to enter plays essential role on making appropriate decisions on market development (Smith, 1956; Edwards et al., 1973). Initial market entry decisions have typically concentrated on country evaluations based on macro-economic data (Cavusgil et al., 2003; Hawkins \& Mothersbaugh, 2010). While suitable in providing an initial screening of countries, other issues may also provide important insights in assessing international market opportunities (Keegan, 1982; Reeder, 1987; Cavusgil, 1997). Douglas and Craig (2001) reported that a wide range of contextual factors exert may impact on consumption choices and contribute to within-country heterogeneity. Market segmentation is one of the most popular techniques for choosing appropriate market (Arndt, 1974; Wind \& Cardozo, 1974; Bonomo \& Shapiro, 1983, 1984). In fact, an appropriate market segmentation improves market share for business organizations (Sudharshan \& Winter, 1998). Abratt (1993) determined the variables used in segmenting markets, the criteria used to form segments, the criteria implemented to select target segments, and the marketing actions

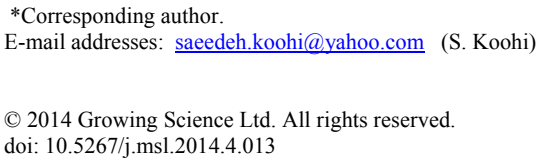


applied to reach the chosen segments. Hassan and Craft (2005) provided some support for existing link between global market segmentation decisions and strategic positioning options.

Freytag and Clarke (2001) investigated the characteristics of industrial markets in association with some of the major industrial market segmentation techniques (Kamakura \& Russell, 1989). To shed light on different market circumstances, they described a scale with simple market transactions at one end and complex relationship management at the other, recommending that the segmentation approach must be different for each end of the spectrum. They presented a general industrial segmentation model directed towards situations. The model stressed the relative importance of having a deep understanding of the customers' characteristics, requirements, future directions, as well as identification of what type of overall relationship could be required by the customer (Dwight \& Baptista, 1995).

During the past few years, there have been tremendous changes on ecommerce and many business owners try to offer their products and services through internet (Brennan et al., 2007; Sousa \& Lages, 2011). Freytag and Clarke (2001) investigated the characteristics of industrial markets in association with some of the major industrial market segmentation models. To understand the various market characteristics, they explained a scale with simple market transactions at one end and complex relationship management at the other, implying that the segmentation method must be different for each end of the spectrum. They presented a general industrial segmentation model directed towards situations characterized by relationships and networks. The model emphasized the relative importance of having a deep insight of the customers' characteristics, requirements, future directions, as well as identification of what type of overall relationship is needed by the customer. Simkin (2008) reported that good market segmentation plays essential role on business to business market development.

Sheng and Mullen (2011) proposed a new model for export market opportunity analysis by integrating the marketing-based overall market opportunity index (OMOI) (Hass, 1995) with the economic-based gravity framework in order to evaluate export market potential, in total and for specific industries. They reported that market size, economic intensity, geographic and language distance, and regional trade agreements were predictors of export market attractiveness from a US firm's perspective. Sakarya et al. (2007) presented a tool composed of four criteria specific to the preliminary assessment of emerging markets (EM) as international expansion opportunities. They reported that case application exposed strong future market potential, manageable level of cultural distance, supportive and developing local industry and positive customer receptiveness for foreign products and business.

Market entrance is another important component of business development and it must receive special attention when a business model is formed (Hutt, 1995; Hutt \& Speh, 2010; Ojala \& Tyrväinen, 2008; Kumar, 2004).

\section{The proposed study}

In this paper, we propose an empirical investigation to determine important factors influencing on selection of petrochemical market more specifically PVC market. The proposed study considers the following eight hypotheses,

1. Infrastructure issues influence on selection of petrochemical target market.

2. Potentials of having good market influence on selection of petrochemical target market.

3. Rules and regulations influence on selection of petrochemical target market.

4. Political issues influence on selection of petrochemical target market.

5. Economic factors influence on selection of petrochemical target market.

6. Cultural factors influence on selection of petrochemical target market. 
7. Purchasing characteristics influence on selection of petrochemical target market.

8. Buyer's positions influence on selection of petrochemical target market (Bann, 1993).

The proposed study of this paper designs a questionnaire consists of 35 questions where 4 questions are devoted to political issues, 6 questions are related to rules and regulations, 4 questions are associated with cultural affairs, 6 questions are concerned with infrastructures, 7 questions are related to market potentials and finally 4 questions are associated with purchase occasions. All questions are designed in 5-item Likert scale by adopting the method developed by Wood and Robertson (2000). The population of this survey includes all 127 professionals in petrochemical industry. The sample size is calculated as follows,

$n=\frac{N \times z_{\alpha / 2}^{2} \times p \times q}{\varepsilon^{2} \times(N-1)+z_{\alpha / 2}^{2} \times p \times q}$,

where $N$ is the population size, $p=1-q$ represents the yes/no categories, $z_{\alpha / 2}$ is CDF of normal distribution and finally $\varepsilon$ is the error term. Since we have $p=0.5, z_{\alpha / 2}=1.96$ and $N=127$, the number of sample size is calculated as $n=97$. All participants in our survey were male and Fig. 1 shows other personal characteristics of the participants.

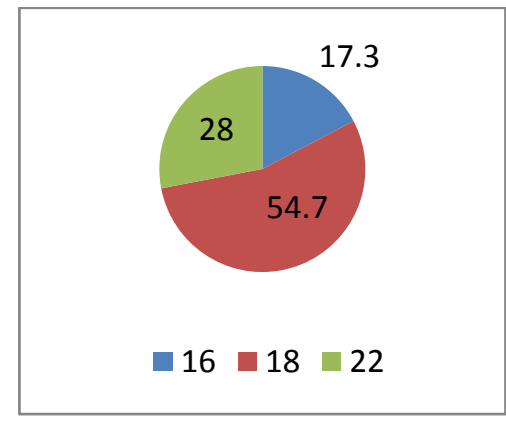

Years of education

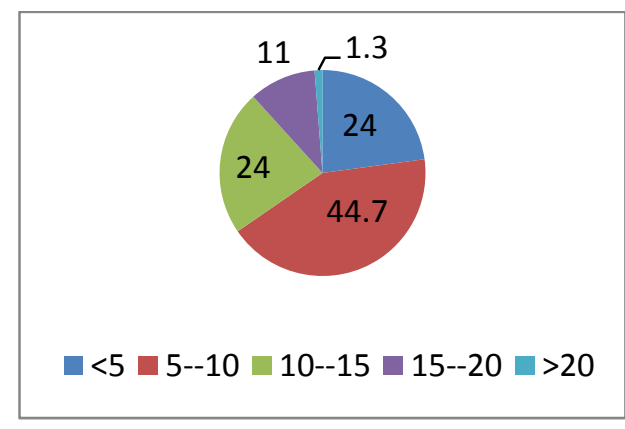

Years of job experience

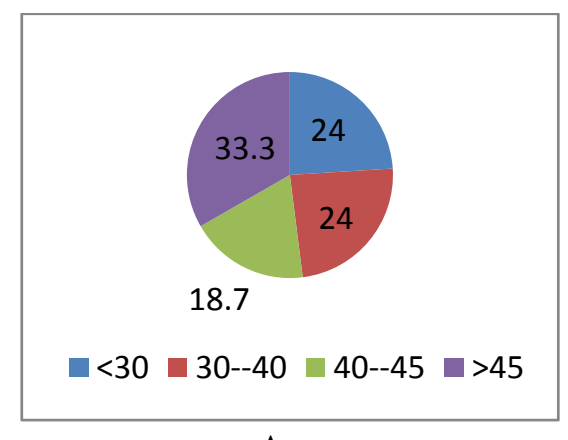

Age

Fig. 1. Personal characteristics of the participants

As we can observe from the results of Fig. 1, most participants were middle aged people, maintained a master's degree and had at least 5 years of job experience. Cronbach alpha has been calculated as 0.83 , which is well above the minimum acceptable level. In order to do any statistical observation, we need to find out whether the data are normally distributed or not. Table demonstrates the summary of our findings,

\section{Table 1}

The summary of Kolmogorov-Smirnov (Z) test

\begin{tabular}{lccc}
\hline Factor & $\mathrm{N}$ & $\mathrm{Z}$ & Sig. \\
\hline Political & 97 & 1.49 & 0.01 \\
Cultural & 97 & 1.374 & 0.046 \\
Rules and regulations & 97 & 2.515 & 0.00 \\
Economic & 97 & 1.719 & 0.005 \\
Infrastructure & 97 & 1.941 & 0.000 \\
Market potential & 97 & 1.603 & 0.01 \\
Buyers' potentials & 97 & 2.804 & 0.00 \\
Buyer's positions & 97 & 3.686 & 0.00 \\
\hline
\end{tabular}


As we can observe from the results of Table 1, none of the factors is normally distributed when the level of significance is $5 \%$. Therefore, we need to use non-parametric tests to examine the hypotheses of the survey.

\section{The results}

We now use Spearman correlation test to examine the relationships between various components of the survey. Table 2 demonstrates the summary of our findings.

Table 2

The summary of Spearman correlation test

\begin{tabular}{|c|c|c|c|c|c|c|c|c|}
\hline Factor & Political & Cultural & Regulations & Economic & Infrastructure & $\begin{array}{l}\text { Market } \\
\text { potential }\end{array}$ & $\begin{array}{l}\text { Buyers' } \\
\text { potentials }\end{array}$ & $\begin{array}{l}\text { Buyer's } \\
\text { positions }\end{array}$ \\
\hline Political & 1 & & & & & & & \\
\hline Cultural & $0.422^{* *}$ & 1 & & & & & & \\
\hline Regulations & 0.121 & 0.159 & 1 & & & & & \\
\hline Economic & 0.027 & -0.14 & $0.351^{* *}$ & 1 & & & & \\
\hline Infrastructure & -0.001 & 0.188 & 0.091 & 0.012 & 1 & & & \\
\hline Market potential & 0.011 & $-0.243^{*}$ & $0.260^{*}$ & $0.479^{* *}$ & $0.410^{* *}$ & 1 & & \\
\hline Buyers' potentials & 0.162 & $0.276^{* *}$ & $0.206^{*}$ & 0.055 & $0.371^{* *}$ & $0.221^{*}$ & 1 & \\
\hline Buyer's positions & -0.142 & 0.116 & $0.208^{*}$ & $-0.315^{* *}$ & -0.048 & $-0.212^{*}$ & $0.255^{*}$ & 1 \\
\hline
\end{tabular}

As we can observe from the results of Table 2, there is a positive and meaningful relationship between political and cultural factors $(r=0.422$, Sig. $=0.01)$ and between buyers' potentials and cultural factors $(r=0.276$, Sig. $=0.01)$. In addition, there is a positive and meaningful relationship between economic and regulations $(r=0.351$, Sig. $=0.01)$ and positive and meaningful relationship between market potentials and economic $(\mathrm{r}=0.479$, Sig. $=0.01)$ and infrastructure $(\mathrm{r}=0.410$, Sig. $=$ 0.01 ). In our survey, there was a negative and meaningful relationship between market potential and cultural factors $(r=-0.243$, Sig. $=0.05)$ and between buyer's positions and economic factors $(r=-$ 0.315 , Sig. $=0.01)$. We have also performed Freedman test to learn the effect of each component on development of target market and Table 3 demonstrates the results.

Table 3

The results of Freedman test

\begin{tabular}{lcccccccc}
\hline Factor & Political & Cultural & Regulations & Economic & Infrastructure & Market potential & Buyers' potentials & Buyer's positions \\
\hline Mean value & 5.15 & 1.46 & 5.30 & 4.03 & 2.39 & 4.93 & 5.99 & 5 \\
Rank & 4 & 8 & 3 & 6 & 7 & 5 & 2 \\
\hline
\end{tabular}

According to the results of Table 3, Buyers' positions are number one priority followed by buyers' potentials, rules and regulations, political affairs, market potential, economic and infrastructure as well as cultural issues. We have also performed a binomial test to verify the effects of eight factors on market development and the results indicate that only the effect of cultural factors was insignificant and the effects of other factors were significant $(\alpha=0.05)$.

\section{Conclusion}

In this paper, we have performed an empirical investigation to study the effects of eight factors on development of target market. The survey have designed a questionnaire and distributed it among some experts and using binomial test, it has confirmed that except one factor, cultural affairs, the other issues including political, cultural, regulations, economic, infrastructure, market potential, buyers' potentials and buyer's positions influence on market development. The implementation of Freedman test has indicated that Buyers' positions are number one priority followed by buyers' potentials, rules and regulations. 


\section{Acknowledgement}

The authors would like to thank the anonymous referees for constructive comments on earlier version of this paper.

\section{References}

Abratt, R. (1993). Market segmentation practices of industrial marketers. Industrial marketing management, 22(2), 79-84.

Arndt. (1974). Market Segmentation. Bergent oslo Tromso: Universitestsforlaget.

Bann, M. (1993). Taxonomy of buying decision approaches. Journal of Marketing, 57, 38-56.

Bonomo, T. V., \& Shapiro, B. P. (1983). Segmenting The Industrial Market. Lexington: Lexington Books.

Bonomo, T. V., \& Shapiro, B. P. (1984). Evaluating market segmentation approaches. Industrial Marketing Management, 275-268.

Brennan, R. Canning, L., \& McDowell, R. (2007). Business to Business Marketing. London: SAGE Publication Ltd.

Cavusgil, S. (1997). Measuring the potential of emerging market: an indexing approach. Business Horizon, 40 (1), 87-91.

Cavusgil, S. T., Kiyak, T., \& Yeniyrt, S. (2003). Complementary approaches o preliminary foreign market opportunity assessment: country clustering and country ranking. Industrial Marketing Management, 33, 607-617.

Douglas, S. P., \& Craig, S. C. (2001). The role of context in assessing international marketing opportunities. Industrial Marketing Review, 28(2), 150-162.

Dwight, G. L., \& Baptista, J. P. (1995). Grow to be Great: Breaking the Downsizing Cycle. New York: The Free Press.

Edwards, R. C., Gordon, D. M., \& Reich, M. (1973). Labor Market Segmentation. A Research Report to the U. S. Department of Labor.

Freytag, P. V., \& Clarke, A. H. (2001). Business to business market segmentation. Industrial Marketing Management, 30, 473-486.

Hass, R. (1995). Business Marketing, six edition. San Diego: San Diego State University.

Hassan, S. S., \& Craft, S. H. (2005). Linking global market segmentation decisions with strategic positioning options. Journal of Consumer Marketing, 81-89.

Hawkins, D. I., \& Mothersbaugh, D. L. (2010). Consumer Behavior: Building Marketing Strategy (1th ed). New York: Mc Graw - Hill.

Hutt, J. (1995). Industrial Marketing Management. New York: Dryton Press.

Hutt, M. D., \& Speh, T. W. (2010). Business Marketing Management. South western: Cencage Learning.

Kamakura, W. A., \& Russell, G. J. (1989). A probabilistic choice model for market segmentation and elasticity structure. Journal of Marketing Research, 26(4), 379-390.

Keegan, W. J. (1982). Multinational Marketing Management, $2^{\text {nd }}$ edition. New Dehli: Prentice Hall.

Kumar, N. (2004). Marketing as Strategy. Boston: Harvard Business School Press.

Ojala, A., \& Tyrväinen, P. (2008). Market entry decisions of US small and medium-sized software frims. Management Decision, 187-200.

Reeder, R. R., Briety, E. G., \& Reeder, H. B. (1987). Industrial Marketing: Analysis, Planning and Control. New Jersey: Prentice-Hall.

Sakarya, S., Eckman, M., \& HyHegard, K. (2007). Market selection for industrial expansion: assessing opportunities in emerging markets. Industrial Marketing Review, 208-238.

Sheng, S. Y., \& Mullen, M. R. (2011). A hybrid model for export market opportunity analysis. Industrial Marketing Review, 1-33.

Simkin, L. (2008). Achieving market segmentation from B2B sectorisation. Journal of Business \& Industrial Marketing, 23(7), 464-474. 
Smith, W. R. (1956). Product differentiation and market segmentation as alternative marketing strategies. The Journal of Marketing, 21(1), 3-8.

Sousa, C. M., \& Lages, L. F. (2011).The PD scale: A measure of psychic distance and its impact on international marketing strategy. Industrial Marketing review, 28(2), 201-222.

Sudharshan, D., \& Winter, F. (1998). Strategic segmentation of industrial markets. Journal of Business \& Industrial Marketing, 13(1), 8-21.

Wind, Y., \& Cardozo, R. (1974). Industrial market segmentation. Industrial Marketing Management, 3, 153-166.

Wood, V. R., \& Robertson, K. R. (2000). Evaluation Industrial Markets. Industrial Marketing Review, 17(1), 34-55. 